\title{
ENEMIES AND OTHER PERILS OF THE MOUNTAIN BLUEBIRD IN SOUTHWESTERN MANITOBA
}

\author{
by John Lane, 1701 Lorne Avenue, Brandon, Manitoba
}

The Mountain Bluebird (Sialia currucoides) usually makes its appearance in southwestern Manitoba in late March and remains until late October. During this interval many perils beset the bird and mortality is high; this is reflected in the numbers of "built-over" nests found each summer in nestboxes. When one of a breeding pair of bluebirds disappears from any cause, the eggs are abandoned, and another pair of hole-nesters will take over the nestbox and build their nest on top of the original. Only if the bluebird nest contains young will a bereaved parent continue the nest cycle, and then it is customary to find either a female or male parent trying to feed its hungry off spring singlehandedly.

Surprisingly, the early returning Mountain Bluebirds are able to withstand the final blasts of dying winter, including sub-zero temperatures and driving snowstorms, but six weeks later, with the first brood clutches laid, a late May snowstorm can create havoc. Many incubating females appear to panic and abandon their eggs; in some cases they disappear permanently, and it is then common to see only the male at the nest site, vainly guarding the nest and eggs.

One main reason for "built-over" nests is the mortality suffered by Mountain Bluebirds from traffic mishaps. Where a nestline is located along a railroad or by a busy paved highway, many bluebirds pay with their lives for their single-minded pursuit of flying insects. When thus occupied, they pay not the slightest heed to speeding trains or traffic on the highway. In 1970 , for example, we listed two deaths by trains and eight by traffic collisions. Without doubt many other unrecorded fatalities occur.

Among the raptors, Cooper's Hawk appears the main threat, when nestlines are close to cover; in more open areas the Pigeon Hawk is the chief culprit. Bent (1949) lists the Sharpshinned Hawk, along with Cooper's Hawk, as preying on Mountain Bluebirds. In Montana, Power (1966) also includes the Pigeon Hawk, together with the Marsh Hawk and the Common Crow, in his list of enemies of the species. He also thought the Sparrow Hawk was suspect. Without doubt, all the above can be considered occasional enemies.

Several smaller species of birds are also important factors in the life of the Mountain Bluebird. Power (1966) describes in detail encounters between Mountain Bluebirds and Tree Swallows and his findings closely parallel our data in southwestern Manitoba. There appears to be a marked variation in the degree of pugnacity shown by the individual Mountain Bluebird wher it comes to fighting for a nest site. Even when the contest is simply bluebird versus swallow, there is no sure victory for the bluebird, and when the Tree Swallows attack in force, as they often do, the outcome is usually a victory for them. Nevertheless, neither species appears to have full possession until the nest is built and a clutch started, after which serious tilting for that nestbox appears to end.

Bent (1949) quotes a contributor as giving the "Flicker" as an enemy of the Mountain Bluebird in Manitoba, and the same contributor states that the House Sparrow is "no match" for the bluebirds. Locally, the Yellowshafted Flicker is not considered an enemy of the Bluebird, but we now have strong evidence that cock House Sparrows are quite capable of cornering and killing adult bluebirds. One of our nestlines, 100 nestboxes in extent, had to be abandoned in 1970 (Lane and Bauman, 1970) because of a general takeover by House Sparrows. When cleaning out some of these boxes we found three that had the remains of adult Mountain Bluebirds buried 
under the mass of a sparrow nest.

Also, during the summer of $1970, \mathrm{D}$. Randall and I cleaned a nest of House Sparrows from a box on another nestline, and a pair of Mountain Bluebirds immediately started to move in. The pair of dispossessed House Sparrows soon returned and the bluebirds at once retired to a respectful distance. Randall then shot the cock sparrow and the bluebirds quickly flew back to the nestbox, completely ignoring the female sparrow when she returned later.

The Starling is another formidable competitor for nestboxes, but can be excluded by limiting the diameter of the nesthole to one and two-fifths inches. That tiny demon, the House Wren, will often drive out a pair of bluebirds by slipping into the nest and puncturing the eggs, but it can be controlled by keeping the nestboxes well clear of cover. We might mention here that during the past nine years we have checked well over 2000 active nests of Mountain Bluebirds with not a single instance of molestation by the Brown-headed Cowbird.

Power (1966) mentions only one example of nest invasion by Deer Mice but Swenson (1968) reports several cases of almost certain depredation of active bluebird and Tree Swallow nests by this species. Our notes in Manitoba show that for some years invasion of our nestboxes by Deer Mice had been an event of the autumn season. In June, 1969, however, an active nest of the Eastern Bluebird was molested by this rodent (Randall and Lane, 1969). In June, 1970, we checked a Mountain Bluebird nest the day the first egg was laid. Eight days later we found this box filled by a mouse nest interspersed with bluebird feathers. A plump mother Deer Mouse with three babies was in possession, and a search revealed two bluebird eggs in the bottom of the nest, together with the outer wing feathers and the tarsi and feet of an adult bluebird. Since the female bluebird had laid a second egg the day after our first visit, this left but seven days for the bluebird to be killed in some manner, then apparently eaten by the mother mouse, a mouse nest assembled and three babies born. There is no way of knowing what killed the mother bluebird, but the Deer Mice are at least suspect.

In 1968 members of our Junior Birders Club found an instance of predation of an Eastern Bluebird's nest by Eastern Chipmunks (Miller, 1968), and in 1970 we noted further molestations of nestboxes by this species. In the C.P.R. siding at Melbourne, Manitoba, an active nest of Mountain Bluebirds was invaded by chipmunks and two of the young killed by the time we arrived. We faced the nestbox in a new direction and took other steps to keep the vandals out. Near Clariere, Manitoba, a nest of Tree Swallows was also attacked by chipmunks and the naked babies killed. All but three had been removed from the nestbox, to which we were attracted by the appearance of the male Tree Swallow, since his wing feathers were in shreds - mute testimony to his efforts to drive off the invaders.

For the second consecutive year we found that Red Squirrels had moved into one of our nestboxes (Randall and Lane, 1969). Again it was a pair of Mountain Bluebirds that was driven out by the squirrels, and justas in 1969 the mere taking of a few photos was sufficient to prompt the mother squirrel to move her family.

Apparently all species of birds are afflicted with fleas and lice of some kind, but probably these could be considered more of an annoyance than an enemy to their hosts. However, in southwestern Manitoba two other arthropods have, on rare occasions, proven to be real perils to the young of both bluebirds and swallows. These are the Red Pharaoh Ant (Monomorium pharconis, (Lim.)) and the much larger Black Carpenter Ant (Camponotus herculeanus, (de Geer) ) [identifications by Reginald E. Forbes, Agricultural Extension Department, Brandon]. We can be thankful that invasions of nestboxes by these creatures are not numerous, for they must inflict a particularly painful death on the baby birds. In 1970 we found one instance 
of Red Pharaohs ascending to a nest of Mountain Bluebirds on the Griswold-Souris nestline, killing all the young, and a case of Tree Swallows meeting the same fate. In the Camp Hughes area, a small swarm of the Black Carpenters overwhelmed a nestful of half-fledged Mountain Bluebirds, and at this nest we noted the parent birds perched on a high wire, the picture of silent dejection. Clearly they had not been able to cope with the invaders.

From the smallest enemies of the Mountain Bluebird, we now turn to Man who must rate as the greatest peril of all. To point up this statement, our nestlines have suffered over 250 cases of vandalism during the past 12 years of operation; nestboxes have been destroyed by shooting, or have been knocked down, smashed, or simply stolen. In addition, many more have been robbed - in one instance 10 consecutive nests had all the eggs taken on the same day. The parent birds are often shot, or one of a breeding pair is shot, resulting in the abandonment of the nest (see above). Some years ago our junior birders set out eight nestboxes on a fence enclosing a horse run. The first year of operation found no less than seven pairs of bluebirds using the nests, so the lads named this spot "Bluebird Square." All went well with this nestline till the early summer of 1970 , when we found "Bluebird Square" completely shattered, with every nestbox smashed or robbed, and the corpses of two Mountain and one Eastern Bluebirds strewn about.
Not a single successful bluebird nesting was recorded for this spot in 1970 , so completely had the birds been driven out.

Some form of man-caused pollution appears to have reached our breeding populations of Mountain Bluebirds by mid-June, 1970 (Lane and Bauman, 1970 ), and, in the absence of any certain proof, we can only suspect that the deaths of between 200 and 350 young bluebirds were caused by some type of food poisoning, probably of insecticide origin.

Despite all the foregoing, it is a matter for great rejoicing that the exquisite Mountain Bluebird continues to multiply on the Canadian prairies, as does his lovely cousin, the Eastern Bluebird. Both species have shown that, given the necessary nestholes and as much protection as possible, they can and will thrive in our midst, imparting joy and beauty to the eye and ear of the beholder.

\section{LITERATURE CITED}

Bent, A. C. 1949. Life histories of North American thrushes, kinglets, and their allies. Smithsonian Institution. U.S. Nat'l. Mus., Bull. 196.

Lane, J. and V. Bauman. 1970. Tenth annual report of the Brandon Juniors' nesting project. Blue Jay, 28:175.

Miller, W. 1968. Predation of bluebirds by an Eastern Chipmunk. Biue Jay, 26:145.

Power, H. W. 1966. Biology of the Mountain Bluebird in Montana. Condor, 68:366-367.

Randall, D., and J. Lane. 1969. Ninth annual report of the Brandon Juniors' nestbox project. Blue Jay, $27: 215$.

Swenson, J. E. 1968. The Deer Mouse as a nest competition and possible predator on the Mountain Bluebird. Blue Jay, $26: 214$.

\section{OBSERVATIONS OF TURKEYS IN BRITISH COLUMBIA}

\section{by William J. Merilees, Selkirk College, Castlegar, B.C.}

The Turkey, Meleagris gallopavo, was once a native resident species in eastern Canada, but no longer occurs there except where recently introduced (Godfrey, 1966).

In recent years Turkeys have been introduced in the states of Washington and Montana, some of these releases being close to British Columbia. Since then some of these birds have crossed the International Boundary into southern British Columbia (see map). Turkeys have been reported from two locations: the Pend Oreille Valley southeast of Trail in the West Kootenay, and near Newgate, south of Elko in 